American Journal of Applied Sciences 7 (5): 620-627, 2010

ISSN 1546-9239

(C) 2010Science Publications

\title{
Risk and Health Effect of Boric Acid
}

\author{
${ }^{1}$ Ang Swi See, ${ }^{1,2}$ Abu Bakar Salleh, ${ }^{1,3}$ Fatimah Abu Bakar, ${ }^{1,4}$ Nor Azah Yusof, \\ ${ }^{3}$ Ahmed Sahib Abdulamir and ${ }^{5}$ Lee Yook Heng \\ ${ }^{1}$ Laboratory of Industrial Biotechnology, Institute of Bioscience, \\ ${ }^{2}$ Department of Biochemistry, Faculty of Biotechnology and Bimolecular Sciences, \\ ${ }^{3}$ Department of Food Science, Faculty of Food Science and Technology, \\ University Putra Malaysia, Malaysia \\ ${ }^{4}$ Department of Chemistry, Faculty of Science, \\ University Putra Malaysia, 43400 Serdang, Selangor, Malaysia \\ ${ }^{5}$ School of Chemical Science and Food Technology, Faculty of Science and Technology, \\ University Kebangsaan Malaysia, 43600 Bangi, Selangor, Malaysia
}

\begin{abstract}
Problem statement: Boric acid is a pesticide usually used to kill mites, fungi, plants and insect including fleas, termites, cockroaches and wood decay fungi. Besides, it was also used in many fields such as food preservative, in newborn baby's nurseries and antiseptic. Many reports indicated that boric acid poisoning occurred due to the misuse of household product and illegal use of boric acid in food product. In this study, the concern issue was the usage of boric acid that may lead to boric acid poisoning. Approach: This review had shown some information for boric acid such as its usage, the existent method for detection of boric acid in food. Besides, this review also discussed about the toxicology and pharmacokinetic of boric acid and the health impact of boric acid on human and animal. Result: Previous studies showed that food products such as yellow noodles contain boric acid. The boric acid level in most foods was different among the factory and the production period. It is due to the lack of standard measurement during the processing. Conclusion: Since boric acid was harmful to human health and may cause poisoning, hence, the control and the awareness of the usage of boric acid especially in food should be increased. There are numerous methods available for quantification of boric acid such as mannitol titration technique, colorimetric method. Accordingly, the analysis of boric acid is essential.
\end{abstract}

Key words: Boric acid, analytical methods, toxic effect, foods, review

\section{INTRODUCTION}

Boric acid $\left(\mathrm{H}_{3} \mathrm{BO}_{3}\right)$ is a boron compound which is soluble and circulate in plasma (Di Renzo et al., 2007). It is a colorless, water-soluble, salt-like white powder, which have been used as pesticide since 1948. Normally, it is used to kill mites, insects, fungi and algae. For instances fleas, cockroaches, termites and wood decay fungi (Cox, 2004; Woods, 1994).

Borate chemicals and boric acid have been used extensively for industrial purposes and its salts have been used for medication as an antiseptic to kill bacteria and fungi. Normally, it is used in the form of powder and liquid; depending to the target and conditions of pest, boric acid might applied as a spray or aerosol, as well as in the form of tablets, granule, pellets, paste or crystalline (United States Environmental Protection Agency, 1993).

Boric acid plays a role as a "stomach poison" for certain pest such as cockroaches, ants and termites. As an insecticide, it usually applied in bait form or used as a dry powder in which containing a feeding attractant and then added into crevices and creaks so that it forms a layer of dust (United States Environmental Protection Agency, 1996). So boric acid adheres to their legs when the insects move across the powder. Hence, they may ingest the poison when the insects groom themselves. This will causes death due to starvation and dehydration after 3-10 days (Woods, 1994). However, the insecticide mechanism of boric acid on insects has not been satisfactorily developed. Some hypotheses has been suggested including death by starvation owing to

Corresponding Author: Abu Bakar Salleh, Department of Biochemistry, Faculty of Biotechnology and Biomolecular Sciences, University Putra Malaysia, 43400 UPM Serdang, Selangor Darul Ehsan, Malaysia

Tel: +603-89471002 Fax: +603-89371633 
abrasive effect on the cuticle then cause destruction or slow drying of foregut cells (Habes et al., 2006; Cochran, 1995).

Besides that, when boric acid used as an herbicide, it desiccates or disrupts the photosynthesis system in plants. Hence, boric acid is normally used to suppress algae in swimming pools and sewage systems (Cox, 2004). On the other hand, as a fungicide, the fungicidal properties of boric acid prevent the production of conidia or asexual spores of the fungi; hence, it suppresses the growth of fungi. Therefore, boric acid is used as wood preservative in wood industry such as lumber and timber products that controls decay producing fungi (Woods, 1994; Clausen and Yang, 2007).

Boric acid is reported to be used as food preservatives in some foods and food products. Boric acid is used for preserving meats, meat products, caviar and dairy products (Arslan et al., 2008). This is because boric acid is able to inhibit the growth of microorganism, therefore, the preserved food can stay fresh and longer (Normah et al., 1984). Moreover, according to Yiu et al. (2008), boric acid was added to some food products to control starch gelatinization, as well as enhance the color, texture and flavor of the food.

However, because of boric acid contains cumulative toxicity, FAO/WHO Expert Committee declared that boric acid is unsafe to use as food additives. Even though Ministry of Health Malaysia (MDC Legal Advisers, 2004) does not allow boric acid to be used as a food additive, however, it has been reported in some of the local foods in Malaysia such as yellow noodle and fish ball (Siti-Mizura et al., 1991). Moreover, boric acid is harmful to human health if consumed in higher amount. However, due to unawareness of the risk of boric acid, it is continued to be used in the production of food especially noodles and some processed seafood such as fish ball (Yiu et al. 2008).

The idea of this review is to focus on the usage of boric acid especially in food. It also provides some information for boric acid, such as the current methods for the detection of boric acid in food. Besides, this review highlights the toxicology and pharmacokinetic aspects of boric acid and its health impact on human.

Table 1: Level of boric acid in some local foods

\begin{tabular}{lll}
\hline Food products & $\begin{array}{l}\text { Boric acid } \\
\text { concentration mg kg}\end{array}$ & Reference \\
\hline Fish ball & $130-926 \mathrm{ppm}$ & Normah et al. (1984) \\
Kueh teow noodle & $161-489 \mathrm{ppm}$ & Normah et al. (1984) \\
Agar-agar strips & $918 \mathrm{ppm}$ & Siti-Mizura et al. (1991) \\
Fresh prawn & $347 \mathrm{ppm}$ & Siti-Mizura et al. (1991) \\
Mango (pickled) & $819 \mathrm{ppm}$ & Siti-Mizura et al. (1991) \\
\hline
\end{tabular}

Case reports: Many countries such as United Kingdom, Thailand, China as well as Malaysia, have banned the use of boric acid for food preservation. However, boric acid is still being used as food preservative in Malaysia. A number of reports had come out from some local institutions; they tested some Malaysian raw food products to evaluate boric acid level. The reports showed that various local foods contain boric acid such as yellow noodle, koay teow noodle, loh see fun noodle, fish ball, agar-agar strips as shown in Table 1 (Normah et al., 1984; Yiu et al., 2008; Siti-Mizura et al., 1991). Moreover, many reports also found in local newspaper such as The Star and New Strait Time regarding to the incident usage of boric acid in some local foods in Malaysia.

According to Yiu et al. (2008), the concentration level of boric acid in the tested food was different over time and the manufacturers. The amounts of boric acid added by some individual manufacturers were inconsistent and vary from time to time. This is because there was no consistency in measurement of boric acid being added to the foods by some small-scale producers. Moreover, different workers could be handling the addition of boric acid at different production periods. Besides that, amounts of boric acid added by some individual manufacturers are based on approximation rather than exact measurement. Nonuniform or poor mixing of boric acid with the flour and other ingredients during the production process can also cause variation in concentration. In other words, this non-uniformity in concentration over time is attributed to poor control in boric acid usage.

Based on a case report purposed by Hamilton and Wolf (2007), perhaps owing to the problems of quality control procedures during manufacturing process of the noodles, incident of boric acid food poisoning was reported in Malaysia during 1988 at Nine Emperor Gods Festival. Most of the victims were children aged between 2.5-11 years were died in this incident. The victims were affected by excess ingestion of boric acid and also the aflatoxin contamination was a factor. In loh see fun noodle. Boric acid was used during the final production stage of loh see fun noodle to enhance the color, texture, flavor and crunchiness of the noodle (Chao et al., 1991; Cheng, 1992). This incident implied that boric acid was used illegally in this area (Strong et al., 2001).

Besides, boric acid poisoning may occur if the handling process was carried out in improper way. Borate compound such as boric acid used as aqueous solutions in household disinfectants, cleaners, pesticides and medical therapy. For medical purpose, ointment and skin powders applied for diaper rash and 
burns treatments. Moreover, it also used for body cavities as irrigants (Cox, 2004; Hamilton and Wolf, 2007; Strong et al., 2001). According to Heindel et al. (1997), boric acid was reported to be used for medicinal and no medicinal purpose. It is used to treat skin infections as an antiseptic. However, documented report was shown that deaths have happened usually involve young children and newborn baby. This is because they are possible to exposure to these household products. Some cases caused by the treatment of diaper rash by using boric acid powder have been reported. It caused fatalities and accidental poisonings of infants (Baliah et al., 1969). Reported symptoms of acute exposure of infant and children included diarrhea, vomiting, erythematic, exfoliation, desquamation of the skin and central nervous system irritation (Strong et al., 2001). In additional, it was reported that death incident had occurred in the preparation of infant's formula where it contained 2.5\% of aqueous solution boric acid instead of sterile water (Hamilton and Wolf, 2007; Wong et al., 1964).

Many case reports regarding to the dangerous and boric acid poisoning have been reviewed. The poisoning incidence happens in everywhere and perhaps the common forms of toxicity is because by ingestion of food and mishandling. Therefore, with the consideration of medical purpose, the applications of boric acid should be prevented due to the potential lethality and toxicity of borates compound. Besides, explanation and awareness of its toxicity is essential because of the exposure in industrial and consumer exposure to boron (Sabuncuoglu et al., 2006).

Pharmacokinetic features: Review about pharmacokinetic of boric acid had been purposed previously, hence, the kinetic properties of boric acid were summarized in this review. According to Baselt (2004), boric acid is an inorganic acid. It was easily absorbed via broken skin surface and mucus membranes (Hamilton and Wolf, 2007; Murray, 1998). Few studies reported that boric acid is entirely absorbed by the oral route in humans and animals. Moreover, serum boron concentration also indicates boric acid was $100 \%$ and quickly absorbed (Moore, 1997). This suggests that borate compound is not strongly bound by body proteins or tissues. Since boric acid is water soluble compound, it is widely distributed in body tissues, such as brain, liver and kidney (Murray, 1998; Moore, 1997).

Besides, some studies have indicated that absorbed boric acid is rapidly dispersed all over the body water through passive diffusion in both animals and human. As shown from in vivo clinical study, through the direct contact of boric acid to the skin, dermal absorption of boric acid was much lower than the absorption of boric acid into human via dietary intake. This suggested that the boron compound might not be able to pass through the skin in humans or animals (Strong et al., 2001; Murray, 1998; Goldbloom and Goldbloom, 1953; Pfeiffer et al., 1945; Valdes-Dapena and Arey, 1962).

Boric acid and borates are not metabolized beyond the boric acid structure $\mathrm{B}\left(\mathrm{OH}_{3}\right)$ because it needs highenergy to break the boron-oxygen bond (Murray, 1998; $\mathrm{Ku}$ et al., 1991; Naghii and Samman, 1997). Nevertheless, borate compound forms reversible coordination bonds with some biological chemicals that contain adjacent hydroxyl groups such as mannitol (Woods, 1994; Strong et al., 2001). It is eliminated largely unaltered, mainly by kidney, through glomerular filtration as in animals and humans. Therefore, boric acid is mainly excreted in the urine as the regulation of boric acid is basically regulated by the kidney during homeostasis process (Kot, 2009; Sutherland et al., 1999).

In human, it is reported that the excretion half life of boric acid is between 13 and $21 \mathrm{~h}$, whereas for rats, the elimination half life is $4.6 \mathrm{~h}$. Study In humans was reported that after $96 \mathrm{~h}$ administration of boric acid, around $92-94 \%$ of boric acid might excrete in the urine whereas in rats, it is absorbed completely within $24 \mathrm{~h}$ (Strong et al., 2001; Kot, 2009; Jansen et al., 1984a; 1984b; Usuda et al., 1998). According to $\mathrm{Ku}$ et al. (1991) and Kot (2009) in animals bone is the only tissue in which boron accumulates significantly above blood level instead of soft tissue.

Toxic effects of boric acid: Boric acid normally used for preservation of food products. It can cause to health problem if the food containing boric acid was ingested by human as boric acid and borates are toxic to cell. Hence, it is deleterious to health and its usage is not recommended (Yiu et al., 2008). For new born baby, the possible lethal doses are in between 3-6 g, whereas 15-20 g total for adults (Litovitz et al., 1988). The common symptoms from several incidents of boric acid poisoning included coughing, eye irritation, vomiting and oral irritation (Baker and Bogema, 1986). However, the toxicity mechanisms of boron compound remain unclear (Kot, 2009). According to Moseman (1994), the usual amount of boron in urine, blood and soft tissues, normally in the range below $0.05 \mathrm{mg} \mathrm{kg}^{-1}$ and do not above $10 \mathrm{mg} \mathrm{kg}^{-1}$. Some boric acid poisoning cases reported that as high as $2 \mathrm{~g} \mathrm{~kg}^{-1}$ boric acid was found in liver tissue and brain (Kot, 2009; Moseman, 1994). 
Table 2: Boric acid acute toxicity profile (United States Environmental Protection Agency, 1993)

\begin{tabular}{ll}
\hline Acute toxicity & Toxicity level \\
\hline Acute oral toxicity/rat & LD50 $=3.5-4.08 \mathrm{~g} \mathrm{~kg}^{-1}$ \\
Acute oral toxicity/beagle dog & LD50 $>0.631 \mathrm{~g} \mathrm{~kg}^{-1}$ \\
Acute dermal toxicity/rabbit & LD50 $>2 \mathrm{~g} \mathrm{~kg}^{-1}$ \\
Acute inhalation toxicity/rat & LC50>0.16 mg L-1 \\
Acute eye irritation toxicity/rabbit & Conjunctiva irritation clearing by day 4 \\
\hline
\end{tabular}

From laboratory testing, toxicity of boric acid is quite low when ingested. In mice, it is around $3450 \mathrm{mg} \mathrm{kg}^{-1}$ for acute oral LD50, whereas for rats the range is between $2660-5140 \mathrm{mg} \mathrm{kg}^{-1}$. Meanwhile, for inhaled boron compounds, it has low inhalation toxicity with the LC50 values in mice $0.89-21.1 \mathrm{mg} \mathrm{L}^{-1}$ (Smyth et al., 1969; Weir and Fisher, 1972). Table 2 shows the acute toxicity profile for boric acid. In rabbits, boric acid is poorly absorbed across intact skin, the $\mathrm{LD}_{50}$ value in rabbits was more than $2 \mathrm{~g} \mathrm{~kg}^{-1}$ when applied to skin. However, the absorption increases in damaged or burned skin. Therefore, boric acid was classified as very low toxicity for skin irritation (Hamilton and Wolf, 2007).

For cancer effect studies, boric acid was classified as a group E carcinogen by the US EPA. However, boric acid is not considered a potent human carcinogen based on laboratory animals test which showed that boric acid is no carcinogenicity (United States Environmental Protection Agency, 1993). These studies were based on chronic feeding on rats (Strong et al., 2001; Weir and Fisher, 1972). Moreover, few reports stated that there was no proof to show for the potential of boric acid to cause mutation according to in vivo and in vitro study (Strong et al., 2001; Benson et al., 1984; Landolph, 1985).

Many reviews and case reports had provided information of boric acid regarding to the effects in humans from exposure to inorganic borates (Culver and Hubbard, 1996). The chronic "No Effect' levels for humans was reported to be about $1 \mathrm{~g} \mathrm{day}^{-1}$ of boric acid (2.5 $\mathrm{mg} \mathrm{B} \mathrm{kg}^{-1}$ day $^{-1}$ ) and approximately $5 \mathrm{mg} \mathrm{B} \mathrm{kg}^{-1}$ day $^{-1}$ was reported for the chronic adverse effect level. It was according to the symptoms of anorexia, indigestion and exfoliative dermatitis (Strong et al., 2001).

Several studies on mice and rats reported that boric acid has toxicity to the male reproductive system (Weir and Fisher, 1972; Lee et al., 1978). When the tested animals were exposed to low level of boric acid, the quantity of the sperm that produced by the animals were reduced than unexposed animal (Cox, 2004). Meanwhile boric acid suppressed the sperm release from testes when the animals were treated with high amount of boric acid and causes atrophy. This is attributed to the fact that boric acid causes degeneration of the spermatogenic epithelium, it inhibits the DNA formation in sperm cell and hence, reduces fertility and sterility. It impairs fertility in male rodents (Cox, 2004; $\mathrm{Ku}$ and Chapin, 1994). However, based on a report from US EPA 1993, the exact mechanism of action by which inhibition of spermiation take place in vivo have not been characterized completely. According to a report from Ku et al. (1991), chronic exposure of boric acid in animal may cause central nervous system problem, cutaneous disorder and retarded growth (Pfeiffer et al., 1945; Weir and Fisher, 1972; Lee et al., 1978; Roe et al., 1972).

Boric acid will form stable complexes with hydroxyl compounds such as carbohydrate components (Cox, 2004; Hamilton and Wolf, 2007; Strong et al., 2001). Recent research findings suggested that boric acid might reduce ATP production in chick muscle (Geyikogglu and Turkez, 2007). In a study, boric acid caused a decrease of metabolite concentrations such as glucose, glycogen and lactate due to the formation of complexes among boron and hydroxyl compounds. Moreover, boric acid causes the damage of some parts of mitochondria. Lack of ATP metabolite and the defects of mitochondrial metabolism are harmful on cell survival and function, mainly in highly energydependent tissues, such as skeletal muscle (Schapira, 1998). It is well known that energy generation for supporting muscle contraction in cell is largely originated from mitochondria (Cogswell et al., 1993). Hence, destroyed mitochondria might be the reason for ATP reduction. According to Geyikogglu and Turkez

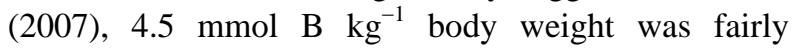
dangerous to muscle energy metabolism.

Analytical method: Owing to the deleterious effect of boric acid to health, hence, monitoring and determination of boric acid level in foods is very important. Numerous methods are available to determine the level of boric acid either in food or in urine and blood samples.

According to Williams (2000) in order to detect boric acid in food, preliminary test by using turmeric paper was used. A strip of turmeric paper was immersed in acidified liquid samples and let the paper dry spontaneously. If the borate or boric acid is present, the paper turn from red to dark blue green color. Previously, the occurrence of borate in cerebrospinal fluid or urine specimen was determined by using turmeric acid paper test. However, the turmeric paper test eventually found to be unreliable because it might give false-positive result and is not satisfactory for quantitative measurements (Goldbloom and Goldbloom, 1953; Valdes-Dapena and Arey, 1962). 
Besides, titrimetric method was also used to determine boric acid in food (Williams, 2000). Solution of food samples was treated with lime water to convert the boric acid into free state. A standard alkali solution cannot be used for titrating a weak acid such as boric acid, hence, before titrated with $\mathrm{NaOH}$, polyhydroxyl compound such as mannitol was added into the solution to form complexes to convert boric acid into a strong monobasic acid. A constant pink color will appear when phenolphthalein was added in the solution before the titration. Therefore, boric acid concentration in food sample was calculated using the titrated volume of alkali. According to Siti-Mizura et al. (1991), titrimetric was less sensitive and it requires a huge amount of food sample to analyze compared to spectrophotometric method.

Recently, spectrophotometric method is the most common and available method to access boric acid level. Based on spectrophotometric method that used to analyze boric acid in food have so far been described by many other researchers, for instances, atomic absorption spectrophotometric method (Williams, 2000), colorimetric procedures using carminic acid and curcumin solution (Siti-Mizura et al., 1991; Williams, 2000; Ogawa et al., 1979; Yoshida et al., 1989). The principle of this method is that the boron compound may react with curcumin in nonaqueous acid solution to form a color complex. The intensity of color is measured with a spectrophotometer to detect and quantitate boric acid. This procedure can be applied in food sample as well as for blood, urine and stomach contents. Assessment of this method implicated that the curcumin spectrophotometric method is simple and good in quantitativeness, the detection limit is about $1 \mu \mathrm{g} \mathrm{mL}^{-1}$ as a concentration in the test tube (Williams, 2000; Suzuki, 2005). According to Siti-Mizura et al. (1991), from practical point of view, curcumin spectrophotometric method is preferred because it proved to be accurate and gave the least variation.

Besides, curcumin spectrophotometric method have been improved by Yoshida et al. (1989) to detect boric acid content, so that it is appropriate to be used and to avoid the cases of boric acid poisoning. The detection range of boric acid is between $10 \mu \mathrm{g} \mathrm{mL}^{-1}$ to $5 \mathrm{mg} \mathrm{mL}^{-1}$. In this experiment, they extracted boric acid to $1 \mathrm{~mL}$ of the sample solution, then, sulfuric acid was added, along with 2-ethyl-1, 3-hexanediol/chloroform (an EHD solution) and then shook followed by centrifuged. The extract was then dehydrated with anhydrous sodium sulfate before used for the coloring reaction sample. The extract solution was added with, curcumin/acetic acid solution and concentrated sulfuric acid. After that, the mixture was mix thoroughly and left at room temperature for the formation of Rosocyanin. Next, the excess protonated curcumin was decomposed by adding with ethanol. Then, the absorbance was measured at $550 \mathrm{~nm}$.

Besides the conventional methods that have been discussed, the concern of biosensor technique in food quality control and food industry is increasing nowadays. Development of biosensor provides another method to ease the analysis in industrial products. It gives benefits as alternatives to traditional methods. This is because of the special characteristic of biosensor such as fast response, simplicity and specificity (Keow et al., 2007; Mello and Kubota, 2002; Shan et al., 2007). Biosensor is an analytical tool that integrates selective biological recognition elements with an electronic transducer. The transducer produces a signal which is proportional to the analyte concentration into a quantifiable electrical response such as potential, light absorption and current. The response later will process as a readable output (Chaubey and Malhotra, 2002; Lei et al., 2006). Biological recognitions such as enzymes, antibodies, DNA and microorganisms are the key to specificity for biosensor technologies (Keow et al., 2007; D’Souza, 2001). Meanwhile, the transducer of a biosensor, for instances potentiometric, amperometric, Ion-Sensitive Field Effect Transistors (ISFETs), calorimetric and optical device was used to monitor the reaction of the biological compound for analyte target (Mello and Kubota, 2002; Shan et al., 2007) Hence, with the current potential and situation of biosensor technology, its application in determination of boric acid as a novel tool could be further developed.

\section{CONCLUSION}

As a conclusion, commonly boric acid is used as a chemical preservative in food products to prevent alteration and degradation of food product by microorganisms to enhance the quality of the products. However, excessive addition of these preservatives prove to be harmful to consumers, due to the tendency of boric acid to induce some adverse health problems such as coughing, eye irritation, vomiting, difficulty breathing and even death. It can cause toxicity to the cell. The usage of boric acid in other fields such as household and nurseries should carry out in proper way to avoid boric acid poisoning. Since the boric acid usage is not recommended in foodstuff, it is essential to monitor boric acid levels in foodstuffs in view of their importance for human health and food safety. Therefore, the development of suitable and inexpensive analysis methods of these preservatives is also been needed for food safety. Current development of 
analytical method, biosensor may offer such advantages. It was played a role as diagnostic devices for rapid, sensitive and inexpensive tool to analysis boric acid so to reduce the usage and the abuse of using boric acid to make food product.

\section{REFERENCES}

Arslan, M., M. Topaktas and E. Rencuzogullari, 2008. The effects of boric acid on sister chromatid exchanges and chromosome aberrations in cultured human lymphocytes. Cytotechnology, 56: 91-96. DOI: $10.1007 / \mathrm{s} 10616-007-9094-\mathrm{z}$

Baker, D.M. and S.C. Bogema, 1986. Ingestion of boric acid by infants. Am. J. Emergency Med., 4: 358-361. DOI: 10.1016/0735-6757(86)90309-8

Baliah, T., H. Macleish and K.N. Drummond, 1969. Acute boric acid poisoning: Report of an infant successfully treated by peritoneal dialysis. Can. Med. Assoc. J., 101: 166-168. http://search.ebscohost.com/login.aspx?direct=true $\& d b=m n h \& A N=5806886 \&$ site $=$ ehost-live

Baselt, R.C., 2004. Disposition of Toxic Drugs and Chemicals in Man. 7th Edn., Biomedical Publications, Foster City, ISBN: 0-9626523-6-9, pp: 1254.

Benson, W., W. Birge and H. Dorough, 1984. Absence of mutagenic activity of sodium borate (borax) and boric acid in the Salmonella preincubation test. Environ. Toxicol. Chem., 3: 209-214.

Chao, T.C., S.M. Maxwell and S.Y. Wong, 1991. An outbreak of aflatoxicosis and boric acid poisoning in Malaysia: A clinicopathological study. J. Pathol., 164 : 225-233. DOI: 10.1002/path.1711640307

Chaubey, A. and B.D. Malhotra, 2002. Mediated biosensors. Biosensors Bioelect., 17: 441-456. $\quad$ DOI: $10.1016 /$ S09565663(01)00313-X

Cheng, C.T., 1992. Perak, Malaysia, mass poisoning. Tale of the nine emperor gods and rat tail noodles. Am. J. Forensic Med. Pathol., 13: 261-263. http://journals.lww.com/amjforensicmedicine/Fullt ext/1992/09000/Perak,_Malaysia,_Mass_Poisoning _Tale_of_the_Nine.20.aspx

Clausen, C.A. and V. Yang, 2007. Protecting wood from mould, decay and termites with multicomponent biocide systems. Int. Biodeteriorat. Biodegradat., $\quad 59$ : 20-24. DOI: 10.1016/j.ibiod.2005.07.005

Cochran, D.G., 1995. Toxic effects of boric acid on the German cockroach. Cell. Mol. Life Sci., 51: 561-563. DOI: 10.1007/BF02128743
Cogswell, A.M., R.J. Stevens and D.A. Hood, 1993. Properties of skeletal muscle mitochondria isolated from subsarcolemmal and intermyofibrillar regions. Am. J. Phys. Cell Physiol., 264: 383-389. http://ajpcell.physiology.org/cgi/content/abstract/2 64/2/C383

Cox, C., 2004. Boric acid and borates. J. Pesticide Reform, 24: 10-15. http://www.pesticide.org/boricacid.pdf

Culver, B.D. and S.A. Hubbard, 1996. Inorganic boron health effects in humans: An aid to risk assessment and clinical judgment. J. Trace Elem. Exp. Med., 9: 175-184. DOI: 10.1002/(SICI)1520670X(1996)9:4<175::AID-JTRA5>3.0.CO;2-Q

D’Souza, S.F., 2001. Microbial biosensors. Biosensors Bioelect., 16: 337-353. DOI: 10.1016/S09565663(01)00125-7

Di Renzo, F., G. Cappelletti, M.L. Broccia, E. Giavini and E. Menegola, 2007. Boric acid inhibits embryonic histone deacetylases: A suggested mechanism to explain boric acid-related teratogenicity. Toxicol. Applied Pharmacol., 220: 178-185. DOI: 10.1016/j.taap.2007.01.001

Geyikogglu, F. and H. Turkez, 2007. Acute toxicity of boric acid on energy metabolism of the breast muscle in broiler chickens. Biologia, 62: 112-117. DOI: 10.2478/s11756-007-0018-3

Goldbloom, R.B. and A. Goldbloom, 1953. Boric acid poisoning: Report of four cases and a review of 109 cases from the world literature. J. Pediat., 43: 631-643. DOI: 10.1016/S0022-3476(53)80304-5

Habes, D., S. Morakchi, N. Aribi, J.P. Farine and N. Soltani, 2006. Boric acid toxicity to the German cockroach, Blattella germanica: Alterations in midgut structure and acetylcholinesterase and glutathione S-transferase activity. Pesticide Biochem. Physiol., 84: 17-24. DOI: 10.1016/j.pestbp.2005.05.002

Hamilton, R.A. and B.C. Wolf, 2007. Accidental boric acid poisoning following the ingestion of household pesticide. J. Forensic Sci., 52: 706-708. DOI: 10.1111/j.1556-4029.2007.00420.x

Heindel, J., P. Fail, J. George and T. Grizzle, 1997. Reproduction toxicology of boric acid. Environ. Health Perspect., 105: 275-276. PMID: PMC1470241

Jansen, J.A., J. Andersen and J.S. Schou, 1984a. Boric acid single dose pharmacokinetics after intravenous administration to man. Arch. Toxicol., 55: 64-67. DOI: 10.1007/BF00316588

Jansen, J.A., J.S. Schou and B. Aggerbeck, 1984b. Gastro-intestinal absorption and in vitro release of boric acid from water-emulsifying ointments. Food Chem. Toxicol., 22: 49-53. DOI: 10.1016/02786915(84)90052-8 
Keow, C. M., F. Abu Bakar, A.B. Salleh, L.Y. Heng, R. Wagiran and L.S. Bean, 2007. An amperometric biosensor for the rapid assessment of histamine level in tiger prawn (Penaeus monodon) spoilage. Food Chem., 105: 1636-1641. DOI: 10.1016/j.foodchem.2007.04.027

Kot, F.S., 2009. Boron sources, speciation and its potential impact on health. Rev. Environ. Sci. Biotechnol., 8: 3-28. DOI: 10.1007/s11157-0089140-0

Ku, W.W. and R.E. Chapin, 1994. Mechanism of the testicular toxicity of boric acid in rats: In vivo and in vitro studies. Environ. Health Perspect., 102: 99-105. PMID: 7889890

Ku, W.W., R.E. Chapin, R.F. Moseman, R.E. Brink, K.D. Pierce and K.Y. Adams, 1991. Tissue disposition of boron in male fischer rats. Toxicol. Applied Pharmacol., 111: 145-151. DOI: 10.1016/0041-008X(91)90143-3

Landolph, J.R., 1985. Cytotoxicity and negligible genotoxicity of borax and borax ores to cultured mammalian cells. Am. J. Ind. Med., 7: 31-43. DOI: 10.1002/ajim.4700070105

Lee, I.P., R.J. Sherins and R.L. Dixon, 1978. Evidence for induction of germinal aplasia in male rats by environmental exposure to boron. Toxicol. Applied Pharmacol., 45: 577-590. DOI: 10.1016/0041008X(78)90119-9

Lei, Y., W. Chen and A. Mulchandani, 2006. Microbial biosensors. Anal. Chim. Acta, 568: 200-210. DOI: 10.1016/j.aca.2005.11.065

Litovitz, T.L., W. Klein-Schwartz, G.M. Oderda and B.F. Schmitz, 1988. Clinical manifestations of toxicity in a series of 784 boric acid ingestions. Am. J. Emerg. Med., 6: 209-213. DOI: 10.1016/0735-6757(88)90001-0

Mello, L.D. and L.T. Kubota, 2002. Review of the use of biosensors as analytical tools in the food and drink industries. Food Chem., 77: 237-256. DOI: 10.1016/S0308-8146(02)00104-8

MDC Legal Advisers, 2004. Food Act and Regulation: All Amendment up to April, 2004: Act 281. MDC Publisher Sdn. Bhd. Kuala Lumpur, ISBN: 967-700808-0, pp: 394.

Moore, J.A., 1997. An assessment of boric acid and borax using the IEHR evaluative process for assessing human developmental and reproductive toxicity of agents. Reprod. Toxicol., 11: 123-160. DOI: 10.1016/S0890-6238(96)00204-3

Moseman, R.F., 1994. Chemical disposition of boron in animals and humans. Environ. Health Perspect., 102: 113-117. PMID: PMC1566637/
Murray, F.J., 1998. A comparative review of the pharmacokinetics of boric acid in rodents and humans. Biol. Trace Element Res., 66: 331-341. DOI: 10.1007/BF02783146

Naghii, M.R. and S. Samman, 1997. The effect of boron on plasma testosterone and plasma lipids in rats. Nutr. Res., 17: 523-531. DOI: 10.1016/S02715317(97)00017-1

Normah, A., K.A. Ku Hasnah and M.H. Zainab, 1984. Penyalahgunaan asid borik dalam makanan. Teknol. Makanan, 3: 54-56.

Ogawa, S., M. Toyoda, Y. Tonogal, Y. Ito and M. Iwaida, 1979. Colorimetric determination of boric acid in prawns, shrimp and salted jelly fish by chelate extraction with 2-ethyl-1, 3-hexanediol. J. Assoc. Official Anal. Chem., 62: 610-614. PMID: 479088

Pfeiffer, L.C.C., E.L.F. Hallman and L.I. Gersh, 1945. Boric acid ointment: A study of possible intoxication in the treatment of burns. J. Am. Med. $\quad$ Assoc., 128: 266-274. DOI: 10.1001/jama.1945.02860210022006

Roe, D.A., D.B. McCormick and R.T. Lin, 1972. Effects of riboflavin on boric acid toxicity. J. Pharm. Sci., 61: 1081-1085. DOI: 10.1002/jps.2600610709

Sabuncuoglu, B.T., P.A. Kocaturk, O. Yaman, G.O. Kavas and M. Tekelioglu, 2006. Effects of subacute boric acid administration on rat kidney tissue. Clin. Toxicol., 44: 249-253. DOI: 10.1080/15563650600584386

Schapira, A.H.V., 1998. Inborn and induced defects of mitochondria. Ar. Neurol, 55: 1293-1296. DOI: 10.1001/archneur.55.10.1293

Shan, D., Q. Shi, D. Zhu and H. Xue, 2007. Inhibitive detection of benzoic acid using a novel phenols biosensor based on polyaniline-polyacrylonitrile composite matrix. Talanta, 72: 1767-1772. DOI: 10.1016/j.talanta.2007.02.007

Siti-Mizura, S., E.S. Tee and H.E. Ooi, 1991. Determination of boric acid in foods: Comparative study of three methods. J. Sci. Food Agric., $\quad$ 55: 261-268. DOI: 10.1002/jsfa.2740550211

Smyth, J.H.E., C.P. Carpenter, C.S. Weil, U.C. Pozzani, J.A. Striegel and J.S. Nycum, 1969. Range-finding toxicity data: List VII. Am. Ind. Hyg. Assoc. J., 30: 470-476. DOI: 10.1080/00028896909343157

Strong, P.L., I.K. Robert and C.K. William, 2001. Boric Acid and Inorganic Borate Pesticides. In: Handbook of Pesticide Toxicology, Strong, P.L. (Ed.)., 2nd Edn., Academic Press, San Diego, ISBN: 978-0-12-426260-7, pp: 1429-1437. 
Sutherland, B., L.R. Woodhouse, P. Strong and J.C. King, 1999. Boron balance in humans. J. Trace Elements Exp. Med., 12: 271-284. DOI: 10.1002/(SICI)1520-670X(1999)12:3<271::AIDJTRA10>3.0.CO;2-B

Suzuki, S. and K. Watanabe, 2005. Drugs Poisons Humans: A Handbook of Practical Analysis. Springer Berlin, Heidelberg, ISBN: 978-3-54022277-4, pp: 672.

Usuda, K., K. Kono, Y. Orita, T. Dote and K. Iguchi et al., 1998. Serum and urinary boron levels in rats after single administration of sodium tetraborate. Arch. Toxicol., $\quad 72$ : 468-474. DOI: 10.1007/s002040050530

United States Environmental Protection Agency, 1993. Boric Acid. United States Environmental Protection Agency. Washington, DC. http://www.epa.gov/oppsrrd1/REDs/factsheets/002 4fact.pdf

United States Environmental Protection Agency, 1996. Report of the food quality protection act (FQPA) tolerance reassessment eligibility decision (TRED) for boric acid/sodium borate salts. United States Environmental Protection Agency. http://www.epa.gov/oppsrrd1/REDs/boric_acid_tre d.pdf

Valdes-Dapena, M.A. and J.B. Arey, 1962. Boric acid poisoning; three fatal cases with pancreatic inclusions and a review of the literature. J. Pediatr., 61: 531-546. DOI: 10.1016/S0022-3476(62)80144-9
Weir, J.R.J. and R.S. Fisher, 1972. Toxicologic studies on borax and boric acid. Toxicol. Applied Pharmacol., 23: 351-364. DOI: 10.1016/0041008X(72)90037-3

Williams, S., 1984. Food Additive. In: Official Methods of Analysis of Association of Official Analytical Chemist International. 14th Edn., Association of Official Analytical Chemists, Arlington, VA., pp: 1141.

Wong, L.C., M.D. Heimbach, D.R. Truscott and B.D. Duncan, 1964. Boric acid poisoning: Report of 11 cases. Can. Med. Assoc. J., 90: 1018-1023. PMID: PMC1922689/

Woods, W.G., 1994. An introduction to boron: History, sources, uses and chemistry. Environ. Health Perspect., 102: 5-11. PMID: 7889881

Yiu, P.H., J. See., A. Rajan and C.F.J. Bong. 2008. Boric acid levels in fresh noodles and fish ball. Am. J. Agric. Biol. Sci., 3: 476-481. http://www.scipub.org/fulltext/AJAB/AJAB32476481.pdf

Yoshida, M., T. Watabiki and N. Ishida, 1989. Spectrophotometric determination of boric acid by the curcumin method. Nihon Hoigaku Zasshi, 43: 490-496. DOI: 10.1007/3-540-27579-7_48 